\title{
Pengaruh Strategi Inkuiri, Group Investigation dan Motivasi Berprestasi Terhadap Hasil Belajar Siswa SMA
}

\author{
${ }^{\mathbf{1}}$ Tsamarul Hizbi, ${ }^{\mathbf{2}}$ Sapiruddin, ${ }^{\mathbf{3}}$ Badrul Wajdi \\ ${ }^{1,2,3}$ Prodi Pendidikan Fisika, FMIPA, Universitas Hamzanwadi Jln. TGKH. M. Zainuddin \\ Abdul Madjid No. 132 Pancor Selong, Lombok Timur, NTB, 83611 \\ Email: tsamarulhizbi@hamzanwadi.ac.id
}

\begin{tabular}{|c|c|}
\hline Article Info & bstract \\
\hline $\begin{array}{l}\text { Article History } \\
\text { Received: } 28 \text { Mei } 2021 \\
\text { Revised: } 26 \text { June } 2021 \\
\text { Published: } 30 \text { June } 2021\end{array}$ & \multirow{2}{*}{$\begin{array}{l}\text { This study aims to determine; (1) The difference between the physics learning } \\
\text { outcomes of high school students who were taught using inquiry strategies and } \\
\text { those taught with group investigation, (2) The effect of the interaction between } \\
\text { learning strategies and achievement motivation on learning outcomes of high } \\
\text { school students, (3) Differences in learning outcomes of high school students } \\
\text { who have motivation High achievers were taught with inquiry strategy with } \\
\text { students who were taught by group investigation., (4) Differences in physics } \\
\text { learning outcomes of high school students with low achievement motivation } \\
\text { were taught using inquiry strategy with students who were taught with group } \\
\text { investigation (1) There were differences in physics learning outcomes for high } \\
\text { school students those who were taught with inquiry strategies with students } \\
\text { who were taught with group investigation., (2) There was an interaction effect } \\
\text { between learning strategies and achievement motivation on the learning } \\
\text { outcomes of high school students., (3) There were differences in physics } \\
\text { learning outcomes for high school students with high achievement motivation } \\
\text { to be studied. show with the Inquiry strategy with students who were taught } \\
\text { with group investigation., (4) There was no difference in the results of studying } \\
\text { physics for high school students who had low achievement motivation learned } \\
\text { by inquiry strategy with students who were taughtwith group investigation. }\end{array}$} \\
\hline $\begin{array}{l}\text { Keywords } \\
\text { Inquiry strategy, gr } \\
\text { investigation, achie } \\
\text { motivation and stuc } \\
\text { learning outcomes. }\end{array}$ & \\
\hline Info & Abstrak \\
\hline $\begin{array}{l}\text { SejarahArtikel } \\
\text { Diterima: } 28 \text { Mei } 2021 \\
\text { Direvisi: 26 Juni } 2021 \\
\text { Dipublikasi: } 30 \text { Juni } 2021\end{array}$ & \multirow{2}{*}{$\begin{array}{l}\text { Perbedaan hasil belajar fisika siswa SMA yang dibelajarkan dengan strategi } \\
\text { Inkuiri dengan siswa yang dibelajarkan dengan group investigation., (2) } \\
\text { Pengaruh interaksi antara strategi pembelajaran dan motivasi berprestasi } \\
\text { terhadap hasil belajar siswa SMA., (3) Perbedaan hasil belajar fisika siswa } \\
\text { SMA yang memiliki motivasi berprestasi tinggi dibelajarkan dengan strategi } \\
\text { Inkuiri dengan siswa yang dibelajarkan dengan group investigation., (4) } \\
\text { Perbedaan hasil belajar fisika siswa SMA yang memiliki motivasi berprestasi } \\
\text { rendah dibelajarkan dengan strategi Inkuiri dengan siswa yang dibelajarkan } \\
\text { dengan group investigation(1) Terdapat perbedaan hasil belajar fisika siswa } \\
\text { SMA yang dibelajarkan dengan strategi Inkuiri dengan siswa yang dibelajarkan } \\
\text { dengan group investigation., (2) Terdapat pengaruh interaksi antara strategi } \\
\text { pembelajaran dan motivasi berprestasi terhadap hasil belajar siswa SMA., (3) } \\
\text { Terdapat perbedaan hasil belajar fisika siswa SMA yang memiliki motivasi } \\
\text { berprestasi tinggi dibelajarkan dengan strategi Inkuiri dengan siswa yang } \\
\text { dibelajarkan dengan group investigation., (4) Tidak terdapat perbedaan hasil } \\
\text { belajar fisika siswa SMA yang memiliki motivasi berprestasi rendah } \\
\text { dibelajarkan dengan strategi Inkuiri dengan siswa yang dibelajarkan dengan } \\
\text { group investigation. }\end{array}$} \\
\hline $\begin{array}{l}\text { Kata kunci } \\
\text { Strategi inkui } \\
\text { investigasi, m } \\
\text { berprestasi da } \\
\text { belajar siswa }\end{array}$ & \\
\hline
\end{tabular}

Sitasi: Hizbi, T., Sapiruddin, S., \& Wajdi, B. (2021). Pengaruh Strategi Inkuiri, Group Investigation dan Motivasi Berprestasi Terhadap Hasil Belajar Siswa SMA. Kappa Journal, 4(2), 80-87. 


\section{PENDAHULUAN}

Di salah satu SMA di Lombok Timur ditemukan ada dua faktor yang mempengaruhi rendahnya hasil belajar fisika, yaitu faktor internal dan eksternal siswa. Faktor internal siswa yang belum mendapatkan perhatian guru diantaranya: minat belajar, motivasi, kreativitas, dan sikap ilmiah siswa. Sedangkan faktor eksternal yang belum mendapatkan perhatian guru adalah pemilihan model, pendekatan, strategi, metode, dan media pembelajaran yang sesuai dengan karakteristik siswa dan materi pembelajaran. Berdasarkan pengamatan langsung di lapangan, proses pembelajaran fisika di SMA masih cenderung berpusat pada keaktifan guru (teacher centered) yang seharusnya dialihkan pada keaktifan siswa (student centered). Agar aktivitas siswa muncul dalam kegiatan pembelajaran, maka guru harus mampu menampilkan kegiatan pembelajaran yang menarik dan menantang. Sugiyanto menyatakan bahwa "Profesionalisme seorang guru bukanlah pada kemampuan mengembangkan ilmu pengetahuannya, tetapi lebih pada kemampuan untuk melaksanakan pembelajaran yang menarik dan bermakna bagi siswanya" (Sugianto, 2007). Jadi, guru harus mampu mengelola kegiatan pembelajaran sehingga siswanya berminat dan termotivasi untuk belajar. Masih dari pengamatan di lapangan, peneliti melihat adanya karakter pembelajaran fisika yang cenderung berorientasi pada tes dan ujian, sehingga guru cenderung hanya menyampaikan fisika sebagai produk dan siswa menghafal informasi faktual, kemudian diperbanyak dengan latihan soal. Evaluasi pembelajaran yang dilakukan guru cenderung berorientasi pada hasil belajar dan mengabaikan evaluasi proses pembelajaran. Akibatnya, kinerja dan motivasi siswa kurang mendapat perhatian guru.

Guru-guru fisika di SMA tersebut menjelaskan bahwa dalam kegiatan pembelajaran fisika jarang menggunakan strategi inkuiri dan group investigation di kelas atau laboratorium. Kegiatan pembelajarannya lebih sering diselenggarakan di kelas dengan metode ceramah. Akibatnya, siswa cenderung lebih banyak mendapatkan pengalaman belajar kognitif, sedang pengalaman belajar afektif, dan psikomotoriknya sangat rendah. Untuk meningkatkan hasil belajar siswa, guru dituntut mempunyai kompetensi dan ketrampilan yang memadai dalam menjalankan tugas pokoknya, yaitu merencanakan, melaksanakan, dan menilai hasil pembelajaran. Yang termasuk ketrampilan dalam merencanakan pembelajaran, diantaranya adalah memilih strategi dan metode pembelajaran yang sesuai dengan karakteristik peserta didik dan materi pelajaran yang akan disampaikan.

Beberapa strategi pembelajaran yang memenuhi karakteristik fisika di antaranya adalah strategi pembelajaran konstruktivisme atau generative, strategi pembelajaran berbasis masalah, strategi pembelajaran kooperatif, strategi group investigation dan strategi pembelajaran inkuiri. Strategi pembelajaran inkuiri dan group investigation (GI) jarang diterapkan di SMA. Ditinjau dari hakekat sains yang mencakup konsep, proses, produk, dan sikap ilmiah, maka group investigation dan penemuan sendiri dalam pembelajaran sains adalah sesuatu yang seharusnya dilakukan, sebab sains berkembang pesat melalui aktivitas proses ilmiah termasuk di dalamnya jujur dalam group investigation dan obyektif dalam proses menemukan konsep fisika. Dengan demikian, materi fisika tidak hanya disampaikan dalam bentuk produk yang berupa fakta-fakta, prinsip-prinsip, hukum-hukum dan teori-teori, tetapi pembelajaran fisika juga harus memperhatikan proses untuk mendapatkan pengetahuan dan diharapkan dapat mengembangkan sikap jujur, obyektif, tekun, teliti, dan terbuka.

Strategi pembelajaran yang dapat digunakan dalam pembelajaran fisika diantaranya adalah kooperatif group investigation dan inkuiri. Penerapan strategi kooperatif group investigation dan inkuiri dapat membantu siswa untuk menemukan dan memahami konsep fisika sebagai produk IPA melalui penemuan sendiri dan investigation group dalam proses pembelajaran fisika di sekolah/madrasah, namun sedikit sekali SMA yang menggunakan tersebut, padahal beberapa penelitian sudah ada tentang komparasi strategi pembelajaran terhadap hasil belajar dan komparasi motivasi berprestasi terhadap hasil belajar. Beberapa penelitian tersebut yaitu; (1) pengaruh penggunaan metode inkuiri terbimbing dan inkuiri bebas termodifikasi terhadap 
prestasi belajar fisika ditinjau dari sikap ilmiah peserta didik (Tarono, 2006). Kesimpulan dari penelitian ini adalah; terdapat pengaruh yang signifikan penggunaan metode inkuiri terbimbing dengan inkuiri bebas termodifikasi, yaitu peserta didik yang diperlakukan dengan metode inkuiri terbimbing mempunyai prestasi lebih tinggi dari pada peserta didik yang diberi perlakuan dengan metode inkuiri bebas termodifikasi, (2) pengaruh strategi pembelajaran matematika realistik dan motivasi berprestasi terhadap prestasi belajar dan sikap siswa pada bidang studi matematika (Dimyati, 2012). Kesimpulan hasil penelitian ini adalah prestasi belajar matematika siswa SMP kelas VIII antara kelompok siswa yang memiliki tingkat motivasi berprestasi (tinggi dan rendah) menunjukkan adanya perbedaan. Kelompok siswa yang memiliki tingkat motivasi tinggi memiliki prestasi lebih tinggi jika dibandingkan dengan kelompok siswa yang memiliki motivasi berprestasi rendah. Persamaan penelitian ini adalah sama-sama menerapkan motivasi berprestasi sebagai variabel moderator. Perbedaannya adalah pada variabel terikatnya, yaitu peneliti akan melihat hasil belajar fisika, sedangkan penelitian di atas melihat hasil belajar matematika. Hasil belajar yang diteliti pada penelitian tersebut adalah hasil belajar matematika yang merupakan sama-sama bidang eksakta. Jadi, hasil penelitian tersebut menunjukkan ada kaitan erat antara motivasi berprestasi dengan hasil belajar eksakta khususnya bidang fisika di SMA.

Selain itu, ada juga penelitian yang dilakukan oleh Sakti yang berjudul: the effect of problem-based learning strategy versus direct learning and achievement motivation toward learning outcomes of concept understanding and critical thinking ability in economy's lesson for students class $x$ of sman 1 Sakra Timur. (Hadi Gunawan Sakti, 2014). Hasil penelitian ini diantaranya: Ada perbedaan hasil belajar pemahaman konsep yang signifikan antara siswa dengan motivasi berprestasinya tinggi dengan motivasi berprestasi rendah. Kesimpulan yang lain ada perbedaan hasil belajar kemampuan berpikir kritis yang signifikan antara siswa dengan motivasi berprestasinya tinggi dengan motivasi berprestasi rendah.Penelitian yang dilakukan oleh Wardana dkk, (I Wyn Setia Wardana dkk, 2013) dengan judul pengaruh model pembelajaran group investigation berbantuan asesmen proyek terhadap prestasi belajar IPA siswa kelas V Sekolah Dasar gugus III Tampaksiring, menyimpulkan bahwa terdapat perbedaan yang signifikan hasil belajar antara kelompok siswa yang mengikuti model pembelajaran Group Investigation (GI) berbantuan asesmen proyek dengan kelompok siswa yang mengikuti model pembelajaran konvensional.

Faktor lain yang mempengaruhi hasil belajar siswa diantaranya motivasi berprestasi, motivasi berprestasi merupakan rangsangan atau dorongan dalam diri individu yang dapat menimbulkan keinginan seseorang dalam melakukan sesuatu untuk mencapai sukses. Motivasi terkait dengan kebutuhan dan tujuan seseorang yang ingin dicapai. Karena itu, motivasi berprestasi itu mempunyai dimensi (1) kemampuan untuk sukses, (2) berupaya mencapai keberhasilan, (3) sulit atau mudahnya tugas, (4) sukses karena keberuntungan, dan (5) faktor lain yang mempengaruhi seperti suasana hati (mood), kesehatan, kelelahan dan bantuan orang lain. Kenyataannya motivasi berprestasi siswa masih sangat bervariasi. Atas dasar uraian di atas, maka peneliti ingin melakukan penelitian komparatif eksperimen tentang pengaruh strategi pembelajaran dan motivasi berprestasi terhadap hasil belajar fisika siswa SMA, Hipotesa yang akan diuji dalam penelitian ini adalah; (1) Perbedaan hasil belajar fisika siswa SMA yang dibelajarkan dengan strategi Inkuiri dengan siswa yang dibelajarkan dengan group investigation., (2) Pengaruh interaksi antara strategi pembelajaran dan motivasi berprestasi terhadap hasil belajar siswa SMA., (3) Perbedaan hasil belajar fisika siswa SMA yang memiliki motivasi berprestasi tinggi dibelajarkan dengan strategi Inkuiri dengan siswa yang dibelajarkan dengan group investigation., (4) Perbedaan hasil belajar fisika siswa SMA yang memiliki motivasi berprestasi rendah dibelajarkan dengan strategi Inkuiri dengan siswa yang dibelajarkan dengan group investigation. 


\section{METODE}

Penelitian ini termasuk penelitian eksperimen. Penelitian eksperimen yang maksud dalam penelitian ini adalah untuk mengetahui ada tidaknya akibat dari penerapan strategi pembelajaran Inkuiri dan GI yang dikenakan pada subyek yang diselidiki atau dicari, caranya adalah dengan membandingkan kelompok eksperimen yang diberi perlakuan strategi Inkuiri dengan kelompok pembanding yang diberi perlakuan strategi GI. Variabel bebas yang lain (variabel moderator) yang ikut mempengaruhi variabel terikat adalah motivasi berprestasi. Rancangan yang digunakan dalam penelitian ini adalah Design Treatment By Level 2x2, yaitu untuk mengetahui pengaruh dua variabel bebas terhadap variabel terikat (hasil belajar). Rancangan penelitian ini ditunujukkan pada Tabel 1 di bawah ini.

Tabel 1. Design Treatment By Level 2x2

\begin{tabular}{|c|c|c|}
\hline \multirow[b]{2}{*}{$\begin{array}{l}\text { Motivasi Berprestasi } \\
\text { (B) }\end{array}$} & \multicolumn{2}{|c|}{ Strategi Pembelajaran(A) } \\
\hline & $\begin{array}{l}\text { Inkuiri } \\
\left(A_{1}\right)\end{array}$ & $\begin{array}{l}\text { Group Investigasi } \\
\left(\mathrm{A}_{2}\right)\end{array}$ \\
\hline Tinggi $\left(B_{1}\right)$ & $\begin{array}{l}\mathrm{A}_{1} \mathrm{~B}_{1} \\
{[\mathrm{X}, \mathrm{Y}]_{11 \mathrm{k}}} \\
\mathrm{k}=1,2, \ldots, \mathrm{n}_{11}\end{array}$ & $\begin{array}{l}\mathrm{A}_{2} \mathrm{~B}_{1} \\
{[\mathrm{X}, \mathrm{Y}]_{21 \mathrm{k}}} \\
\mathrm{k}=1,2, \ldots, \mathrm{n}_{21}\end{array}$ \\
\hline Rendah $\left(\mathrm{B}_{2}\right)$ & $\begin{array}{l}\mathrm{A}_{1} \mathrm{~B}_{2} \\
{[\mathrm{X}, \mathrm{Y}]_{12 \mathrm{k}}} \\
\mathrm{k}=1,2, \ldots, \mathrm{n}_{12}\end{array}$ & $\begin{array}{l}\mathrm{A}_{2} \mathrm{~B}_{2} \\
{[\mathrm{X}, \mathrm{Y}]_{22 \mathrm{k}}} \\
\mathrm{k}=1,2, \ldots, \mathrm{n}_{22}\end{array}$ \\
\hline
\end{tabular}

Keterangan :

$\mathrm{A}_{1}=\quad$ Strategi pembelajaran inkuiri

$\mathrm{A}_{2}=\quad$ Staregi pembelajaran group investigation

$\mathrm{B}_{1}=\quad$ Motivasi berprestasi tinggi

$\mathrm{B}_{2}=\quad$ Motivasi berprestasi rendah

$\mathrm{X}=\quad$ Skor motivasi berprestasi siswa sebagai variabel moderator

$\mathrm{Y}=\quad$ Skor hasil belajar fisika siswa SMA sebagai variabel terikat

$\mathrm{A}_{1} \mathrm{~B}_{1}=$ Kelompok siswa yang memiliki motivasi berprestasi tinggi yang dibelajarkan dengan strategi inkuiri

$\mathrm{A}_{1} \mathrm{~B}_{2}=$ Kelompok siswa yang memiliki motivasi berprestasi rendah yang dibelajarkan dengan strategi inkuiri

$\mathrm{A}_{2} \mathrm{~B}_{1}=$ Kelompok siswa yang memiliki motivasi berprestasi tinggi yang dibelajarkan dengan strategi group investigation

$\mathrm{A}_{2} \mathrm{~B}_{2}=$ Kelompok siswa yang memiliki motivasi berprestasi rendah yang dibelajarkan dengan strategi group investigation

Populasi dalam penelitian ini adalah semua siswa kelas $\mathrm{X}$ pada minat MIPA yang berjumlah 3 kelas. Sampel di ambil menggunakan teknik random kelas, dan didapat 2 kelas sebagai sampel. Untuk kepentingan analisis data dari 2 kelas tersebut akan diambil sampel 33 1/3 siswa kelompok tinggi dan 33 1/3 kelompok rendah di kelas eksperimen dan kontrol dan didapat 22 orang sampel kelas eksperimen dan 22 orang sampel kelas kontrol.

Hasil belajar fisika yang dimaksud dalam penelitian ini adalah materi mata pelajaran fisika materi pokok suhu dan kalor dalam kawasan ranah kognitif yang telah ditetapkan dalam kurikulum telah dikuasai oleh siswa. Adapun materi yang dimaksud dalam penelitian ini adalah materi suhu dan kalor kelas $\mathrm{X}$ semester genap yang meliputi tiga kompetensi dasar, yaitu: (1) Menganalisis pengaruh kalor dan perpindahan kalor pada kehidupan sehari-hari, (2) Menyajikan hasil pengukuran besaran fisis dengan menggunakan peralatan dan teknik yang tepat untuk penyelidikan ilmiah, (3) Merencanakan dan melaksanakan percobaan untuk menyelidiki karakteristik termal suatu bahan, terutama kapasitas dan konduktivitas 
kalor(Pernendikbud No. 69 Tahun 2013). Untuk mengukur penguasaan kompetensi tersebut, peneliti menyusun instrumen hasil belajar fisika dalam bentuk tes pilihan ganda yang terdiri dari 20 soal yang sudah tervalidasi dengan lima alternatif jawaban dan satu jawaban benar. Jawaban benar diberi skor 1 dan jawaban salah diberi skor 0 .

Motivasi berprestasi dalam penelitian ini adalah dorongan atau rangsangan yang ada dalam diri siswa yang mendasari siswa untuk belajar dan berupaya mencapai prestasi belajar. Motivasi berprestasi yang diharapkan ditandai oleh dimensi (1) kemampuan untuk sukses, (2) berupaya mencapai keberhasilan, (3) sulit atau mudahnya tugas, (4) sukses karena keberuntungan, dan (5) faktor lain yang mempengaruhi seperti suasana hati (mood), kesehatan, kelelahan dan bantuan orang lain (Margareth E. Gredler,2009). Adapun indikator motivasi berprestasi tinggi dalam penelitian ini meliputi: (1) percaya diri akan kemampuannya, (2) tujuan belajar untuk kepuasan diri, (3) umumnya meraih hasil belajar di atas rata-rata, (4) selalu berusaha keras untuk sukses, (5) selalu mengerjakan tugas sendiri, (6) menyelesaikan tugas demi masa depan, (7) berusaha mencapai hasil belajar yang tinggi, (8) berupaya belajar walaupun lelah. Sedangkan indikator motivasi berprestasi rendah yaitu: (1) tugas yang sulit ditinggalkan, (2) cenderung menyalahkan tugas yang sukar, (3) cenderung memilih tugas yang mudah, (4) guru mudah memberikan nilai, (5) berhasil walaupun tidak belajar, (6) lelah/sakit mempengaruhi sukses, (7) tujuan belajar untuk menghindari hukuman, (8) cenderung mengharapkan bantuan orang lain, (9) selalu puas dengan hasil yang dicapai, (10) kurang giat untuk meraih sukses, dan (11) cenderung bekerjasama dalam mengerjakan tugas (W.S. Winkel, 1991). Untuk mengukur variable motivasi berprestasi dalam penelitian ini peneliti menyusun instrument motivasi berprestasi dalam bentuk angket yang terdiridari 40 soal dengan penilaian menggunakan skala likert. Setiap soal instrument terdiri dari sebuah pernyataan dan lima alternative jawaban, yaitu; Sangat setuju (SS) diberi skor $=5$, Setuju (S) diberi skor $=4$, Ragu-ragu (R) diberi skor $=3$, Tidak Setuju (TS) diberi skor $=2$, dan Sangat tidak setuju (STS) diberi skor $=1$.

Teknik analisis data yang digunakan dalam penelitian ini adalah teknik Analysis of Variance (ANAVA). Sebelum dilakukan analisis dengan ANAVA terlebih dahulu dilakukan beberapa persyaratan pengujian, antara lain: (1) data yang dianalisis berasal dari populasi yang berdistribusi normal, (2) varian kedua kelompok data yang dibandingkan mempunyai varian yang homogen. Pengujian normalitas data yang terkumpul dilakukan dengan uji Kolmogorov Smirnov berbantukan program SPSS 20 atau uji liliefors dalam uji manual (Sudjana, 2005). Untuk pengujian homogenitas varian dari kelompok data yang dibandingkan menggunakan uji Levene test berbantukan SPSS 20. Pengujian hipotesis penelitian dilakukan melalui Analisis Variansi (ANAVA) berbantukan program SPSS 20.

\section{HASIL DAN PEMBAHASAN}

Hasil penelitian yang pertama sejalan dengan hasil penelitian yang dilakukan oleh (Tarono, 2006). Tarono membanding metode inkuiri terbimbing dengan inkuiri bebas termodifikasi, dengan kesimpulan terdapat pengaruh yang signifikan penggunaan metode inkuiri terbimbing dengan inkuiri bebas termodifikasi, peserta didik yang diberikan pembelajaran dengan metode inkuiri terbimbing mempunyai hasil belajar lebih tinggi dari pada peserta didik yang dibelajarkan dengan metode inkuiri bebas termodifikasi. Ternyata pada proses penelitian berlangsung ditemukan beberapa hal antara lain; pada tahapan penerapan kedua metode tersebut terdapat perbedaan, ternyata membuat konstruk pemahaman siswa juga ikut terpengaruh, ikut andilnya guru sebagai pembimbing memberikan efek positif kepada siswa kelas inkuiri terbimbing, siswa lebih terbuka terkait kemampuannya, jika bingung maka siswa bisa minta bimbingan dan sebaliknya. Tetapi pada inkuiri bebas termodifikasi siswa tidak memdapatkan hal tersebut, sehingga hasil belajar kelas inkuiri terbimbing lebih tinggi secara uji statistik dibandingkan dengan kelas inkuiri bebas termodifikasi. Nah pada saat inkuiri diterapkan sebagai strategi pembelajaran bukan 
sebagai metode, justru lebih terbuka, guru dalam ini sebagai fasilitator akan memfasilitasi bahan, media pembelajaran untuk memudahkan siswa untuk memahami dan mendapat pengalaman belajar agar sikap ilmiah siswa makin terbangun, sikap yang dimaksud adalah sikap ingin tahu, ingin mencoba, tanggungjawab dan seterusnya, sehingga wajar hasil belajar siswa pada kelas ikuiri menjadi tinggi. Sementara itu pada kelas GI, siswa terlihat masih belum bisa mengikuti instruksi panduan investigasi, terlihat pada saat siswa mengelompokkan dan analisis data hasil siswa belum benar. Sehingga pada langkah tersebut sering terjadi ada kekeliruan yang terjadi dan pada akhirnya membuat pemahaman yang keliru, dan hal tersebut yang membuat hasil belajar GI lebih rendah dibandingkan dengan kelas inkuiri.

Faktor eksternal yang ikut mempengaruhi hasil belajar dalam penelitian ini adalah variabel motivasi berprestasi. Secara teori siswa dengan motivasi berprestasi tinggi akan memiliki dorongan internal lebih kuat untuk menjadi yang terbaik dikelasnya dibanding dengan siswa yang memiliki motivasi berprestasi rendah, oleh karena itu peneliti tidak membandingkan hasil belajar siswa yang memiliki motivasi berprestasi tinggi dengan rendah.

Hasil penelitian berikutnya yang bisa peneliti bagi kepada pembaca adalah secara uji statistik HO ditolak pada uji hipotesis nihil pengaruh interaksi antara strategi pembelajaran dengan motivasi berprestasi terhadap hasil belajar. Artinya ada hal yang unik yaitu kelompok siswa yang memiliki motivasi berprestasi tinggi cocok dibelajarkan dengan strategi inkuiri, sebaliknya kelompok siswa yang memiliki motivasi berprestasi rendah lebih cocok dibelajarkan dengan strategi GI di kelas GI. Ini berarti ada hasil yang silang antara penerapan strategi pembelajaran dengan motivasi berprestasi. Lebih lanjut adalah kalau dilihat dari varian kelompok siswa dengan motivasi berprestasi tinggi di kelas inkuiri sama-sama tinggi dengan varian hasil belajar siswa kelompok motivasi berprestasi rendah di kelas GI. Pada proses pembelajaran berlangsung yang bisa peneliti diskripsikan adalah Indikator motivasi berprestasi kategori tinggi, seperti; percaya diri akan kemampuannya, tujuan belajar untuk kepuasan diri, umumnya meraih hasil belajar di atas rata-rata, selalu berusaha keras untuk sukses, selalu mengerjakan tugas sendiri dikelompoknya, dan berupaya belajar walaupun lelah (David C. Berliner dan Robert C. Clalfee, 1996). Hal ini berdampak positif pada hasil belajar siswa materi suhu dan kalor, sehingga wajar jika hasil belajar siswa pada kelas inkuiri, khususnya pada kelompok siswa yang memiliki motivasi berprestasi kategori tinggi, sesuai dengan hasil penelitian (Dimyanti, 2012). Hal sebaliknya terjadi pada kelas GI, indikator motivasi berprestasi tinggi tidak berdampak positif pada hasil belajar khususnya pada siswa yang dibelajarkan menggunakan strategi group investigasi. Sebaliknya hasil belajar siswa tinggi pada kelompok siswa yang memiliki motivasi berprestasi rendah.

Hasil penelitian yang ketiga adalah kelompok siswa yang memiliki motivasi berprestasi tinggi lebih cocok dibelajarkan menggunakan strategi inkuiri dibangkan strategi GI, hal tersebut terlihat dari hasil uji statistik dan nampak indikator motivasi berprestasi pada kelas inkuiri yang berdampak positif pada hasil belajar dikelas inkuiri. Tetapi hal unik terlihat pada hipotesis keempat, dimana hipotesis nihil keempat diterima, yang berarti tidak terdapat perbedaan hasil antara siswa yang belajarkan dengan strategi inkuiri maupun GI pada kelompok siswa yang memiliki motivasi berprestasi rendah. Rata-rata dan varian hasil siswa siswa tidak ada perbedaan menurut uji statistik. Sesuai dengan uraian pembahasan di hipotesis penelitian kedua di atas. Kelebihan strategi inkuri dan GI tidak mampu membuat rata-rata hasil belajar di kedua kelas menjadi makin tinggi, atau membuat salah satu kelas menjadi makin tinggi, karena indikator motivasi berprestasi rendah seperti; tugas yang sulit ditinggalkan, cenderung menyalahkan tugas yang sukar, cenderung memilih tugas yang mudah, cenderung mengharapkan bantuan orang lain, selalu puas dengan hasil yang dicapai, kurang giat untuk meraih sukses, dan cenderung bekerjasama dalam mengerjakan tugas. Hal ini berdampak positif pada hasil belajar siswa khususnya materi suhu dan kalor di kelas X. 


\section{KESIMPULAN}

Dari analisis statistic dapat dibuat kesimpulan; (1) Terdapat perbedaan hasil belajar fisika siswa SMA yang dibelajarkan dengan strategi Inkuiri dengan siswa yang dibelajarkan dengan group investigation., (2) Terdapat pengaruh interaksi antara strategi pembelajaran dan motivasi berprestasi terhadap hasil belajar siswa SMA., (3) Terdapat perbedaan hasil belajar fisika siswa SMA yang memiliki motivasi berprestasi tinggi dibelajarkan dengan strategi Inkuiri dengan siswa yang dibelajarkan dengan group investigation., (4) Tidak terdapat perbedaan hasil belajar fisika siswa SMA yang memiliki motivasi berprestasi rendah dibelajarkan dengan strategi Inkuiri dengan siswa yang dibelajarkan dengan group investigation.

\section{SARAN}

Berdasarkan kesimpulan penelitian maka peneliti menyarankan kepada; 1) bagi guru fisika hendaknya menggunakan strategi pembelajaran Inkuiri untuk pembelajaran siswa SMA yang memiliki motivasi berprestasitinggi pada materi suhu dan kalor, menggunakan strategi Inkuiri atau Group Investigation untuk pembelajaran siswa SMA yang memiliki motivasi berprestasi rendah pada materi suhu dan kalor; 2) bagi para peneliti pendidikan, disarankan untuk meneliti pengaruh strategi pembelajaran dan motivasi berprestasi terhadap variable terikat yang untuk melihat lebih jauh perbedaan penggunaan strategi pembelajaran Inkuiri dan Group Investigation.

\section{UCAPAN TERIMA KASIH}

Ucapan terimakasih kepada Anggota Peneliti, Kepala Sekolah, dan semua pihak yang sudah banyak membantu dalam menyelesaikan penelitian ini.

\section{DAFTAR PUSTAKA}

David C. Berliner Dan Robert C Clalfee, (1996) Handbook Of Educational Psychology. New York: Macmillan Library Reverence USA,

Dimyati, D. (2012). Pengaruh Strategi Pembelajaran Matematika Realistik Dan Motivasi Berprestasi Terhadap Prestasi Belajar Dan Sikap Siswa Pada Bidang Studi Matematika.(Disertasi). Disertasi Dan Tesis Program Pascasarjana UM.

Sakti, H. G. (2015). The Effect Of Problem-Based Learning Strategy Versus Direct Learning And Achievement Motivation Toward Learning Outcomes Of Concept Understanding And Critical Thinking Ability In Economy's Lesson For Students Class X Of Sman 1 Sakra Timur. Disertasi Dan Tesis Program Pascasarjana UM.

Wardana, I. W. S., Setuti, N. M., \& Sudatha, I. G. W. (2013). Pengaruh model pembelajaran group investigation berbantuan asesmen proyek terhadap prestasi belajar ipa siswa kelas V Sekolah Dasar Gugus III Tampaksiring. Mimbar PGSD Undiksha, 1.

Margareth E. Gredler, (2009). Learning and Instruction: Theory into Praktice. Sixth Edition (New Jersey, Ohio: Pearson Education inc.

Pernendikbud No. 69 Tahun 2013 Tentang Kerangka Dasar Dan Struktur Kurikulum SMA/MA. (Diakses 04 Februari 2016)

Sudjana, (2005). Metode Statistika. Bandung: Tarsito.

Sugianto, (2007), Pendidikan Dan Latihan Profesi Guru (PLPG) Model-Model Pembelajaran Inovatif Surakarta: UNS Press. 
Tarono, (2006). Pengaruh Penggunaan Metode Inkuiri Terbimbing Dan Inkuiri Bebas Termodifikasi Terhadap Prestasi Belajar Fisika Ditinjau Dari Sikap Ilmiah Peserta Didik UNS.

Trihendradi, C. (2011). Langkah mudah melakukan analisis statistik menggunakan SPSS 19. Yogyakarta: Andi.

W.S. Winkel, (1991). Psykologi Pengajaran Jakarta: Grasindo. 